\title{
PENGARUH PENGETAHUAN DAN SIKAP TERHADAP PARTISIPASI MASYARAKAT DALAM PENGELOLAAN SAMPAH
}

\author{
Rahman $^{1}$, Mansur Sididi $^{2}$, Yusriani $^{3}$ \\ ${ }^{1,2,3}$ Fakultas Kesehatan Masyarakat Universitas Muslim Indonesia \\ Email: yusriani.yusriani@umi.ac.id
}

\begin{abstract}
ABSTRAK
Sampah merupakan masalah terbesar yang dihadapi oleh masyarakat nelayan, yang saat ini belum juga terselesaikan, hal ini dikarenakan banyaknya masyarakat yang masih kurang menyadari arti pentingnya lingkungan sehingga masyarakat tidak peduli dengan masalah yang dihadapi, malah masyarakat membuang sampah disembarang tempat. Tujuan Penelitian untuk menganalisis pengaruh pengetahuan dan sikap terhadap partisipasi masyarakat dalam pengelolaan sampah di kampung nelayan Untia Kota Makassar. Metode penelitian yang digunakan adalah kuantitatif dengan rancangan cross sectional study. Populasi dalam penelitian ini adalah seluruh KK di kampung nelayan Untia sebanyak $135 \mathrm{KK}$. Penentuan besar sampel dihitung dengan menggunakan rumus Slovin. Teknik pengambilan sampel dilakukan secara simple random sampling. Sampel pada penelitian ini sebanyak $100 \mathrm{KK}$. Pengumpulan data dengan menggunakan kuesioner yang telah diuji validitas dan reliabilitas. Analisis data menggunakan uji korelasi Spearman. Hasil penelitian menunjukan bahwa tingkat pengetahuan pengelolaan sampah yang dikategori baik 30 (30\%), untuk sikap yang dikategori rendah $4(4 \%)$, untuk partisipasi yang dikategori rendah 82 (82\%). Ada pengaruh pengetahuan dan sikap terhadap partisipasi masyarakat dalam pengelolaan sampah. Diharapkan seluruh pihak baik dari petugas kelurahan, pemerintah dan tenaga kesehatan untuk dapat memberikan penyuluhan, sosialisasi mengenai pengelolaan sampah agar partisipasi masyarakat dalam pengelolaan sampah dapat meningkat dengan baik.
\end{abstract}

Kata kunci: Nelayan, Partisipasi Masyarakat, Pengetahuan, Sampah, Sikap 


\title{
THE INFLUENCE OF KNOWLEDGE AND ATTITUDE TOWARDS COMMUNITY PARTICIPATION IN WASTE MANAGEMENT
}

\begin{abstract}
Garbage is the biggest problem faced by the fishing community, which has not yet been resolved, this is because many people are still not aware of the importance of the environment so that people do not care about the problems faced, instead people throw garbage in any place. Research Objectives to analyze the influence of knowledge and attitudes on community participation in waste management in the fishing village of Untia, Makassar City. This method of research is quantitative with a cross sectional study design. The population in this study were all families in the fishing village of Untia as many as 135 families. The determination of sample size is calculated using the Slovin formula. The sampling technique is done by simple random sampling. The sample in this study was 100 households. Data collection using a questionnaire. Data analysis using the Spearman Correlation test. The results showed that the level of knowledge of waste management categorized as good was 30 (30\%), for attitudes classified as low 4 (4\%), for participation categorized as low 82 (82\%). There is an influence of knowledge and attitudes towards community participation in waste management. It is expected that all parties, both from village officials, the government and health workers, can provide counseling, socialization regarding waste management so that community participation in waste management can increase properly.
\end{abstract}

Keywords : Fishermen, Community Participation, Knowledge, Trash, Attitude

\section{PENDAHULUAN}

Penanganan sampah pemukiman memerlukan partisipasi aktif individu dan kelompok masyarakat selain peran pemerintah sebagai fasilitator. Ketidak pedulian masyarakat terhadap sampah akan berakibat terjadinya degradasi kualitas lingkungan yang akan mempengaruhi kualitas hidup masyarakat di sebuah wilayah. Degradasi kualitas lingkungan dipicu oleh perilaku masyarakat yang tidak ramah dengan lingkungan, seperti membuang sampah dibadan air (Ismawatu, 2013).

Di Indonesia, data Bank Dunia menyebutkan, produksi sampah padat 120 secara nasional mencapai 151.921 ton per hari. Hal ini berarti, setiap penduduk Indonesia membuang sampah padat rata-rata $0,85 \mathrm{~kg}$ per hari. Data yang sama juga menyebutkan, dari total sampah yang dihasilkan secara nasional, hanya $80 \%$ yang berhasil dikumpulkan. Sisanya terbuang mencemari lingkungan. Sampah selalu menjadi masalah bagi pemerintah, bahkan diperkirakan sampah setiap harinya di Indonesia ini mencapai 200 ribu ton. Sayangnya tingginya volume sampah itu belum tertangani secara baik oleh pemerintah karena berbagai keterbatasan. Dalam beberapa laporan terungkap, jumlah sampah padat di 
kota-kota dunia akan terus naik sebesar $70 \%$ tahun ini hingga tahun 2025, dari 1,3 miliar ton per tahun menjadi 2,2 miliar ton per tahun. Mayoritas kenaikan terjadi di kota-kota di negara berkembang (Manto, dkk. 2014).

Upaya pengurangan sampah masih menjadi pekerjaan rumah bagi

Kementerian Lingkungan Hidup dan Kehutanan (KLHK). Pasalnya, volume sampah sepanjang 2017 tercatat 65,8 juta ton, Direktur Jenderal Pengelolaan Sampah, Limbah dan Bahan Beracun Berbahaya (B3) Rosa Vivien Ratnawati mengatakan proyeksi volume sampah rumah tangga dan sejenis sampah rumah tangga pada 2018 mencapai 66,5 juta ton, Pemerintah menargetkan pengurangan sampah rumah tangga dan sampah sejenis sampah rumah tangga pada 2018 mencapai 15 persen. Hingga 2025, ditargetkan mencapai 30 persen (Malia, 2018).

Upaya pengelolaan untuk mengatasi permasalahan sampah sudah dilakukan, namun belum tuntas. Peran serta masyarakat dibutuhkan dalam mengatasi permasalahan sampah. Pemerintah, masyarakat dan perubahan pola pikir masyarakat terhadap sampah merupakan komponen penting bagi pengelolaan sampah yang memadai.

Secara umum kondisi sanitasi kampung nelayan Untia saat ini masih perlu peningkatan dan perbaikan. Pemukiman yang berada ditepian pantai memperlakukan penampung air limbah domestik baik limbah padat maupun limbah cair tanpa pengelolaan terlebih dahulu. Paradigma masyarakat yang menganggap air akan menghanyutkan limbah yang dibuang harus segera ditanggapi serius oleh pemerintah daerah dan memerlukan penanganan khusus. Menurunnya kualitas lingkungan hidup kampung nelayan Untia dipengaruhi oleh beberapa faktor seperti perilaku hidup masyarakat yang belum sadar sanitasi, beban lingkungan yang makin besar akibat pertambahan jumlah penduduk setiap tahunnya, urbanisasi, serta kurang tersedianya sarana dan prasarana sanitasi. Dengan bertambahnya jumlah penduduk dan penyebaran penduduk ke wilayah yang lebih luas, menyebabkan jumlah timbunan sampah meningkat setiap tahunnya, sehingga sering kita lihat beberapa TPS (Tempat Pembuangan Sementara) yang overload, disamping karena perilaku masyarakat itu sendiri yang suka membuang sampah sembarangan.

Pengelolaan sampah harus dikelola dengan baik dan benar, karena bila tidak akan menjadi tempat perindukan vektor bibit penyakit, seperti lalat, kecoa, tikus, dan anjing. Penyakit yang erat dengan sampah yang tidak dikelola dengan benar antara lain demam berdarah, disentri, thypus, dan lain-lain.

Jumlah penduduk kampung nelayan Untia yang padat memiliki kontribusi terhadap penambahan jumlah sampah, terlebih tidak adanya tempat pembuangan sampah sementara sehingga tanpa adanya pengarahan dari pihak manapun masyarakat melakukan pembuangan sampah ke laut dan lahan terbuka. Kebiasaan buruk masyarakat tersebut memiliki dampak negatif terhadap lingkungan pemukiman dan air laut itu sendiri, dan dikhawatirkan jika masalah ini akan semakin buruk dari 
tahun ke tahun. Untuk menjaga kelestarian lingkungan di sekitar kita maka masyarakat yang ada di kampung nelayan Untia harus terlibat dalam pengelolaan sampah mulai dari rumah tangga.

Berdasarkan pengamatan observasi awal yang diperoleh di kampung nelayan Untia dengan memiliki 135 KK, dilihat bahwa pada umumnya masyarakat tidak menyadari pentingnya pengelolaan sampah yang baik. Mulainya dari penimbulan, penyimpana, pengumpulan, dan pembuangan akhir sampah sangat buruk, karena terdapat begitu banyaknya sampah yang tidak tertangani dengan baik, sehingga persoalan sampah di kampung nelayan Untiasendiri maupun dari RT yang lainnya melakukan pembuangan sampah ada yang kelaut, dilahan yang terbuka dan juga dibakar tetapi sebagian besar masyarakat membuang sampah kelaut.

Selain itu, terdapat banyaknya sampah dibuang begitu saja yang tidak jauh dari beberapa rumah disekitar lahan tersebut, salah satu faktor kurang tersedianya sarana dan prasarana pengelolaan sampah dan perilaku masyarakat itu sendiri. Sehingga sampah yang menumpuk dapat mengakibatkan perkembangan vector yang diantaranya lalat, nyamuk, dan tikus begitu pula menimbulkan bau yang tidak sedap apa bila dilewati, selain membuang kelahan terbuka ada pula masyarakat melakukan pembakaran sampah tanpa melakukan penggalian tanah, ini berakibat masyarakat yang tidak memikirkan apa bila sampah yang dibuang begitu saja dapat beresiko merusaknya lingkungan dan juga pada kesehatan. Tujuan Penelitian ini adalah untuk menganalisis pengaruh pengetahuan dan sikap terhadap partisipasi masyarakat dalam pengelolaan sampah di kampung nelayan Untia Kota Makassar

\section{METODE PENELITIAN}

MATERIAL

Penelitian ini dimulai dari literatur review, pengembangan instrument survei awal sampai menghasilkan isu strategis. Tahap selanjutnya dimulai dari pengembangan instrument berdasarkan isu strategi yang diperoleh, survei pada lokasi penelitian, pengolahan dan analisis data, sampai menghasilkan rekomendasi berdasarkan hasil penelitian

Jenis penelitian yang digunakan adalah kuantitatif yaitu jenis penelitian Observasional dengan cross sectional study yaitu suatu penelitian yang mempelajari hubungan antara variabel independen dengan dependen. Populasi dalam penelitian ini adalah seluruh kepala keluarga di kampung nelayan Untia sebanyak 135 KK. Penentuan besar sampel dihitung dengan menggunakan rumus Slovin. Sampel pada penelitian ini sebanyak $100 \mathrm{KK}$. Teknik pengambilan sampel dilakukan secara simple random sampling. Pengumpulan data dengan menggunakan instrument dalam bentuk kuesioner yang terdiri dari 30 pertanyaan dan telah diuji validitas dan reliabilitas untuk mengetahui pengetahuan, sikap, dan partisipasi masyarakat dalam pengelolaan sampah. Analisis data menggunkaan uji korelasi 
Spearman karena data variabel penelitian berdistribusi tidak normal. Hasil pendataan kuesioner pengetahuan, sikap dan partisipasi masyarakat diukur berdasarkan skor kemudian di olah dan disajikan dalam bentuk tabel.

\section{HASIL DAN PEMBAHASAN}

Pengumpulan data terhadap masyarakat dilakukan dengan membagikan kuesioner. Selanjutnya dilakukan pengolahan data dan dilakukan pemeriksaan ulang mengenai kuesioner dengan mengacu kepada kriteria objektif yang telah ditetapkan sebelumnya serta kelengkapan kuesioner. Data yang diperoleh kemudian diolah dengan menggunakan komputer program kemudian disajikan dalam bentuk table frekuensi. Adapun hasil penelitian diuraikan sebagai berikut :

\section{Karakteristik responden}

Tabel 1. Distribusi Frekuensi Karakteristik Responden

\begin{tabular}{llll}
\hline & \multicolumn{1}{c}{$\begin{array}{c}\text { Karakteristik } \\
\text { Responden }\end{array}$} & Frekuensi & Persentase (\%) \\
\hline Kelompok Usia & $20-29$ & 13 & 13 \\
& $30-39$ & 20 & 20 \\
& $\geq 40$ & 67 & 67 \\
\hline Jenis Kelamin & Laki-laki & 59 & 59 \\
& Perempuan & 41 & 41 \\
\hline Pendidikan & Dasar & 31 & 31 \\
& Menengah & 51 & 51 \\
& Tinggi & 18 & 18 \\
\hline Pekerjaan & Bekerja & 70 & 70 \\
& Ibu Rumah Tangga & 30 & 30 \\
\hline
\end{tabular}

Berdasarkan table 1 menunjukan bahwa mayoritas responden memiliki kelompok usia 40-49 tahun yaitu sebanyak 45 responden (45\%). Jenis kelamin responden yang paling banyak adalah laki-laki yaitu sebanyak 59 responden (59\%). Mayoritas responden memiliki tingkat pendidikan SLTA/SMA/SMU/SMK sebanyak 47 responden (47\%), dan SD sebanyak 31 responden $(31 \%)$. Pekerjaan responden tertinggi adalah ibu rumah tangga sebanyak 30 responden $(30 \%)$, dan terendah pada kelompok petani sebanyak 5 responden $(5 \%)$.

Hubungan Pengetahuan, Sikap Dengan Partisipasi Masyarakat Dalam Pengelolaan Sampah

Tabel 2. Distribusi Hubungan Pengetahuan, Sikap Dengan Partisipasi Masyarakat Dalam Pengelolaan Sampah Di Kampung Nelayan Untia Kota Makassar 


\begin{tabular}{|c|c|c|c|c|c|c|c|}
\hline \multirow{3}{*}{ Vriabel } & \multicolumn{4}{|c|}{ Partisipasi Masyarakat } & \multirow{2}{*}{\multicolumn{2}{|c|}{ Total }} & \multirow{3}{*}{$\begin{array}{c}P \\
\text { Value }\end{array}$} \\
\hline & \multicolumn{2}{|c|}{ Rendah } & \multicolumn{2}{|c|}{ Sedang } & & & \\
\hline & $\mathbf{n}$ & $\%$ & $\mathbf{n}$ & $\%$ & $\mathbf{n}$ & $\%$ & \\
\hline \multicolumn{8}{|l|}{ Pengetahuan } \\
\hline Kurang Baik & 62 & 88,6 & 8 & 11.4 & 70 & 100 & 0,008 \\
\hline Baik & 20 & 66,7 & 10 & 33,3 & 30 & 100 & \\
\hline \multicolumn{8}{|l|}{ Sikap } \\
\hline Negatif & 70 & 85,4 & 16 & 88,8 & 86 & 100 & 1,005 \\
\hline Positif & 12 & 14,6 & 2 & 14,3 & 14 & 100 & \\
\hline
\end{tabular}

Tabel 2, menunjukkan bahwa hubungan pengetahuan dengan partisipasi masyarakat dari 70 responden (100\%), yang memiliki pengetahuan yang kurang baik, yaitu sebanyak 62 orang $(88,6 \%)$ dengan partisipasi masyarakat rendah dan pengetahuan yang baik sebanyak 10 orang $(33,3 \%)$ dengan partisipasi sedang. Sedangkan dari 30 responden (100\%) yang memiliki pengetahuan yang baik, sebanyak 20 orang $(66,7 \%)$ dengan partisipasi masyarakat rendah dan pengetahuan yang kurang baik sebanyak 8 orang (11.4\%) dengan partisipasi masyarakat sedang. Berdasarkan hasil uji statistik fisher's exact test diperoleh nilai $\mathrm{p}=0,008<0,05$ maka $\mathrm{H}_{0}$ diterima dan $\mathrm{H}_{\mathrm{a}}$ ditolak, artinya bahwa ada hubungan antara pengetahuan dengan partisipasi masyarakat dalam pengelolaan sampah di kampong nelayan Untia Kota Makassar.

Tabel 2, menunjukkan bahwa hubungan sikap dengan partisipasi masyarakat dari 14 responden (100\%), yang memiliki sikap yang positif, yaitu sebanyak 12 orang $(14,6 \%)$ dengan partisipasi masyarakat rendah. Adapun sikap negatif dengan pasrtisipasi sedang sebanyak 16 orang $(88,8 \%)$. Berdasarkan hasil uji statistik fisher's exact test diperoleh nilai $\mathrm{p}=0,005<0,05$ maka $\mathrm{H}_{0}$ diterima dan $\mathrm{H}_{\mathrm{a}}$ ditolak, artinya bahwa ada hubungan antara sikap dengan partisipasi masyarakat dalam pengelolaan sampah di kampong nelayan Untia Kota Makassar.

\section{Tingkat Pengetahuan}

Menurut Notoadmojo

(2007)

Pengetahuan adalah hasil dark tahu dan ini terjadi setelah orang melakukan penginderaan (sebagaian besar diperoleh dari indera mata dan telinga) terhadap objek tertentu. Pengetahuan merupakan dominan yang paling penting untuk terbentuknya tindakan seseorang (over behavior) dan pengetahuan dapat diukur dengan melakukan wawancara. sehingga untuk mengetahui tingkat pengetahuan masyarakat peneliti melakukan wawancara kepada sejumlah responden yang telah dipilih sesuai dengan penarikan sampel menggunakan instrumen penelitian yang berisi 7 pertanyaan.

Dari hasil penelitian dapat diketahui bahwa yang berjumlah 70 orang berpengetahuan kurang baik. Hal ini 
dipengaruhi oleh kurangnya informasi yang didapatkan dari sosialisasi mengenai pengelolaan sampah yang dilakukan oleh pemerintah, selain itu juga informasi kurang diperoleh dari tetangga, keluarga dan teman. Sehingga perlu memberikan penyuluhan, sosialisasi mengenai pengelolaan sampah agar masyarakar memiliki pengetahuan yang baik dalam pengelolaan sampah

Menurut Notoadmojo (2003) dalam Wawan dan Desi (2010) faktor-faktor yang mempengaruhi pengetahuan diantaranya adalah pendidikkan, pekerjaan dan umur. Menurutnya, makin Tinggi pendidikan seseorang makin mudah menerima informasi. Jika dilihat dari tingkat pendidikan masyarakat di RT 003/RW 002 Kelurahan Siwalima Kabupaten Kepulauan Aru 47\% berpendidikan SMA sehingga dapat dikatakan bahwa masyarakat pada umumnya mudah menerima informasi dari informan.

Sedangkan menurut Wahid dkk (2007) dalam Furnanda (2012) bahwa kemudahan seseorang untuk memperoleh informasi dapat membantu mempercepat seseorang untuk memperoleh pengetahuan, sehingga dapat dikatakan bahwa masyarakat RT 003/RW 002 Kelurahan Siwalima berpengetahuan kurang baik dalam pengelolaan sampah disebabkan oleh tingkat pendidikan dan kurangnya informasi.

Menurut Notoadmojo (2007), perilaku yang disari dengan pengetahuan dan kesadaran berbeda dengan yang tidak didasari dengan pengetahuan dan kesadaran karena perilaku yang didasari dengan pengetahuan dan kesadaran akan lebih bertahan lama dari pada perilaku yang tidak didasari ilmu pengetahuan dan kesadaran.

Hasil penelitian yang telah dilakukan ini tidak sejalan dengan hasil penelitian yang dilakukan oleh Ismawatu (2013) tentang Gambaran Partisipasi Masyarakat Dalam Pengelolaan Sampah Pada Bank Sampah Ukm Mandiri Di Rw 002 Kelurahan Tamamaung, Kecamatan Panakukang, Kota Makassar. Hasil penelitian Ismawatu menunjukan bahwa tingkat pengetahuan masyarakat dalam kategori baik 75 orang. Karena adanya informasi yang didapat dari sosialisasi mengenai pengelolaan sampah yang dilakukan oleh petugas Bank Sampah, selain itu informasi juga diperoleh dari tetangga, keluarga dan teman.

Namun hasil penelitian ini sejalan dengan hasil penelitian yang telah dilakukan oleh Jailan (2016) tentang system pengelolaan sampah dan upaya penanggulangan sampah di kelurahan dufa-dufa kota ternate. Hasil penelitian Jailan menunjukkan bahwa secara umum pengetahuan masyarakat mengenai pengelolaan sampah masuk dalam kategori kurang baik. Masyarakat kurang mendaptkan informasi mengenai pengelolaan sampah yang baik dari sosialisasi-sosialisasi yang diadakan oleh pemerintah.

Sehingga dapat disimpulkan bahwa informasi dan tingkat pendidikan sangat berpengaruh terhadap tingkat pengetahuan masyarakat RT 003/RW 002 Kelurahan Siwalima Kabupaten Kepulauan Aru. 
Hasil penelitian menunjukan bahwa pilihan responden memilih pilihan jawaban "Benar" pada pernyataan jenisjenis sampah menurut sifatnya yaitu sebanyak 90 responden (90\%). Sedangkan pada pernyataan yang memilih pilihan jawaban "Salah" pada pernyataan sumber-sumber sampah dan manfaat pengelolaan sampah yaitu sebanyak 55 responden (55\%).

Dan tingkat pengetahuan dengan kategori baik 30 (30\%), dan kategori kurang baik 70 (70\%).

Dalam hal ini semakin tinggi pendidikan seseorang maka tingkat pengetahuan juga akan semakin baik karena semakin banyak materi yang diserap dan pendidikan yang tinggi akan menambah wawasan seseorang juga. Berdasarkan mengenai pengetahuan responden dengan pengelolaan sampah yang dikategori kurang baik karena pendidikan yang rendah sehingga pengetahuan responden mengenai pengelolaan sampahpun juga rendah, misalnya pemisahan sampah antara jenis sampah an-organik dan organik responden berpengetahuan rendah tidak bisa membedakan, sedangkan untuk kategori baik karena pengetahuan responden mengenai pengelolaan sampah memiliki wawasan yang luas juga mendapat pengalaman mengenai pengelolaan sampah, misalnya responden sudah dapat memisahkan antara sampah an-organik dan organik.

\section{Sikap}

Dalam penelitian ini sikap adalah pandangan atau tanggapan responden terhadap pengelolaan sampah. Seperti yang telah disebutkan oleh Allport
(1954) dalam Furnanda (2012) bahwa sikap adalah konsep yang dibentuk oleh yoga komponen, yaitu kognitif, afektif dan perilaku. Komponen kognitif berisi semua pemikiran serta ide-ide yang berkenan dengan objek sikap. Isi pemikiran seseorang meliputi hal-hal yang diketahuinya sekitar objek sikap. Dapat berupa tanggapan atau keyakinan, kesan, atribusi, dan penilaian terhadap objek. Adanya component afeksi dark sikap, dapat diketahui melalui perasaan sums atau tidak suka, senang atau tidak senang terhadap objek sikap.

Newcomb, salah seorang ahli psikologi sosial, menyatakan bahwa sikap merupakan kesiapan atau kesediaan untuk bertindak, dan bulan merupakan pelaksanaan motif tertentu. Sikap belum merupakan sesuatu tindakan atau aktivitas, akan tetapi adalah merupakan predisposisi tindakan suatu perilaku. Sikap itu masih merupakan reaksi tertutup, bukan merupakan reaksi terbuka/tingkah laku terbuka.

Jika orang mengenali dan memiliki pengetahuan yang luas tentang objek sikap, disertai perasaan yang positif mengenai kognisinya, maka ia

akan cenderung mendekati (approach) objek sikap tersebut. Sebaliknya, bila orang memiliki anggapan, pengetahuan, dan keyakinan negative yang disertai dengan perasaan tidak senang terhadap objek sikap, maka ia cenderung menjauhinya (Fernanda,2012).

Hasil penelitian menunjukan bahwa nilai tertinggi pada pilihan jawaban "Sangat Setuju" pada pernyataan sisa makanan dan daun-daunan adalah sampah yang mudah membusuk yaitu 
sebanyak 94 responden (94\%). Sedangkan nilai terendah pada pilihan jawaban "Tidak Setuju dan Sangat Tidak Setuju" pada pernyataan yang sama yaitu sebanyak 0 responden $(0 \%)$. Dan sikap masyarakat mengenai pengelolaan sampah untuk kategori Tinggi 14 (14\%), dan sedang 82 (82\%), dan yang rendah 4 (4\%).

Sikap belum tentu terwujud dalam bentuk tindakan, sebab untuk mewujudkan tindakan perlu factor lain, yaitu adanya fasilitas atau sarana dan prasaran sebagai mediator agar sikap dapat meningkat menjadi tindakan. Dilihat dari reaksi responden dengan pengelolaan sampah ternyata sikap responden belum bisa menerima dengan cara-cara pengelolaan sampah yang baik, sehingga banyak sampah yang diabaikan atau dibiarkan begitu saja tanpa memikirkan resiko negative sampai terhadap kesehatan, terjadinya kecelakaan akibat pembuangan sampah secara sembarangan misalnya luka akibat beda tajam seperti besi. Kaca dan sebagainya.

Hal ini Karena kebiasan sikap masyarakat yang kurang dibimbing dengan ilmu kesehatan tentang sampah. Sehingga yang kategori Tinggi 14 (14\%). Ini Karena responden menerima diartikan bahwa responden memperhatikan stimulus yang diberikan dan merespon artinya memberikan jawaban apabila ditanya pengelolaaan sampah dan sedang 82 (82\%), Karena responden bisa menerima juga merespon apabila memberikan pertanyaan mengenai pengelolaan sampah. dan yang untuk rendah 4 (4\%). ini berakibat Karena responden tidak menerima diartikan bahwa responden tidak memperhatikan stimulus yang diberikan dan merespon artinya memberikan jawaban apabila ditanya pengelolaaan sampah.

Menurut Wawan dan Dewi (2010) sikap seseorang dapat berubah Karena factor lain yaitu, sumber dark pesan, isi pecan dan penerima pecan. Pesan atau informasi yang didapatkan masyarakat dari tetangga, teman, ataupun keluarga akan berbeda dengan informasi yang didapatkan langsung dari petugas sanitarian. Pesan atau informasi yang dikirim ketangan orang pertama kemungkinan dapat berbeda jika informasi sempai kepenerima kedua hal ini akan berpengaruh terhadap sikap seseorang pada suatu obyek.

Notoadmojo (2007) berpendapat bahwa sumber daya yang tersedia merupakan pendukung untuk bersikap positif atau negatif terhadap objek atau stimulus tertentu dengan pertimbangan kebutuhan dari pada individu tersebut, dan social budaya juga berperan besar dalam memengaruhi pola piker seseorang untuk bersikap terhadap objek/stimulus tertentu. Dari hasil observasi diketahui bahwa sebagian besar masyarakat memang tidak memiliki wadah pemilihan sampah untuk memisahkan sampahnya.

Hasil penelitian ini tidak sejalan dengan hasil penelitian yang dilakukan oleh Ismawatu (2013) tentang Gambaran Partisipasi Masyarakat Dalam Pengelolaan Sampah Pada Bank Sampah Ukm Mandiri Di RW 002 Kelurahan Tamamaung, Kecamatan Panakukkang,Kota Makassar. Hasil penelitian Ismawatu menunjukan bahwa 
tingkatan sikap masyarakat dalam pengelolaan sampah dikategorikan baik. Namun hasil penelitian ini sejalan dengan hasil penelitian yang telah dilakukan oleh Jailan (2016) tentang system pengelolaan sampah dan upaya penanggulangan sampah di kelurahan dufa-dufa kota ternate. Hasil penelitian Jailan menunjukkan bahwa secara umum sikap masyarakat mengenai pengelolaan sampah masuk dalam kategori sedang. Masyarakat kurang mendaptkan informasi mengenai pengelolaan sampah yang baik dan pola pandang dan pola pikir masyarakat yang masih rendah terhadap pengelolaan sampah dan dalam memperlakukan sampah.

\section{Partisipasi}

Menurut Notoatmodjo (2007), partisipasi masyarakat adalah ikut sertanya seluruh anggota masyarakat dalam memecahkan permasalahanpermasalahan masyarakat tersebut. Dalam penelitian ini yang dimaksud dengan partisipasi masyarakat adalah keikut sertaan masyarakat dalam pengelolaan sampah di daerah tempat Tinggal mereka.

Hasil penelitian ini menunjukan bahwa responden memilih pilihan jawaban "Tidak Pernah" pada pernyataan Membayar retribusi pengelolaan sampah yaitu sebanyak 90 responden (90\%), sedangkan responden memilih pilihan jawaban "Selalu" pada pernyataan Membayar retribusi pengelolaan sampah yaitu sebanyak 0 responden $(0 \%)$. Sedangkan yang dikategori sedang sebanyak 18 responden (18\%), dan yang dikategori rendah sebanyak 82 responden (82\%).

Pada umumnya partisipasi masyarakat terhadap pengelolaan sampah di kelurahan siwalima kabupaten kepulauan aru masih dalam kategori rendah. karena hanya sebagian responden yang berpartisipasi baik. Untuk itu tokoh masyarakat beserta pemerintahan di kelurahan siwalima perlu melakukan sosialisasi agar partisipasi masyarakat lebih baik lagi.

Menurut Mikkelsen (2011) dalam Furnanda (2012) menyebutkan bahwa untuk mengajak atau menumbuhkan partisipasi masyarakat, pada umumnya ada tiga cara yaitu: dengan paksaan melalui peraturan-peraturan isi maupun dengan perintah lisan saja. Partisipasi dengan kesadaran, partisipasi dengan pendidikan, dan sebagainya baik secara langsung Maupin tidak langsung.

Pengelolaan sampah dapat memberikan manfaat besar bagi masyarakat luas dan lingkungan. Untuk itu dibutuhkan partisipasi masyarakat dalam pengelolaan sampah. Karena memberikan manfaat besar bagi kita sendiri, anak cucu kita dan alam sekitar kita.

Didalam partisipasi serial anggota masyarakat dituntut suatu kontribusi aatau sumbangan. Kontribusi tersebut bukan hanya terbatas pada dana dan finansial saja tetapi dapat dibentuk dalam tenaga (daya) dan pemikiran (ide). Dalam hal ini dapat diwujudkan dalam 4M yakni, manpower (tenaga), money (uang), material (benda-benda), dan mind (ide atau gagasan).

Menurut Walgito (1999) dalam Furnanda (2012), partisipasi masyarakat 
memiliki hubungan yang erat antara individu satu dengan individu yang lain atau sebaliknya, jadi terdapat adanya hubungan yang saling timbal balik. Hubungan tersebut dapat antara individu dengan individu, individu dengan kelompok atau kelompok dengan kelompok. Pada umumnya dapatlah dikatakan bahwa tanpa partisipasi masyarakat maka serial kegiatan pembangunan akan kurang berhasil.

Menurut Slamet dalam Suciati (2006) factor-factor internal yang mempengaruhi partisipasi masyarakat adalah Jenis kelamin, usia, tingkat pendidikan, dan mata pencaharian. Factor internal berasal dari individu tu sendiri. Pengetahuan dan sikap merupakan hal yang sangat berpengaruh terhadap tindakan seseorang, (Yusriani, 2018)

\section{KESIMPULAN}

Pnelitian ini menyimpulkan bahwa tingkat pengetahuan masyarakat mengenai pengelolaan sampah dengan kategori baik (30\%) yaitu memiliki pengetahuan yang luas mengenai pengelolaan sampah, dan pada kategori kurang baik (70\%) yaitu kurangnya pengetahuan masyarakat mengenai pengelolaan sampah. Sikap masyarakat di kelurahan siwalima kabupaten kepulauan aru dengan kategori tinggi (14\%) yaitu responden yang dapat memahami setiap pertanyaan yang diberikan dan menjawab semua pertanyaan dengan benar dan tepat, kategori sedang $(82 \%)$ yaitu responden bisa menjawab pertanyaan yang diberikan dengan baik, sedangkan kategori rendah (4\%) yaitu responden tidak memahami pertanyaan yang diberikan mengenai pengelolaan sampah. Tingkat partisipasi masyarakat mengenai pengelolaan sampah dengan kategori sedang (18\%) yaitu masyarakat turut melakukan partisipasi dengan baik, sedangkan dengan kategori rendah $(82 \%)$ yaitu hanya sebagian masyarakat yang turut dalam berpartisipasi baik. Ada hubungan positif antara pengetahuan dan sikap dengan partisipasi masyarakat dalam pengelolaan sampah.

\section{UCAPAN TERIMAKASIH}

Pada kesempatan ini, peneliti ingin mengucapkan terima kasih kepada berbagai pihak yang telah membantu terwujudnya penelitian ini yaitu Rektor Universitas Muslim Indonesia Prof. Dr. Basri Moddin, M.Si. Lembaga Penelitian dan Pengembangan Sumber Daya Universitas Muslim Indonesia (LP2S UMI) atas bantuan pendanaan skim Penelitian Dosen Pemula dan Pimpinan Fakultas Kesehatan Masyarakat Universitas Muslim Indonesia Dr. R. Sudirman, MS.

\section{DAFTAR PUSTAKA}

Agus R. (2011). Aplikasi Metode Penelitian Kesehatan. Yogyakarta: Nuha Medika

Azaludin. (2009). Pengelolaan Sampah Rumah Tangga di Kecamatan Daha Selatan. Jurnal Ilmu Lingkungan, 9(1), 31-38.

Chandra B. (2006). Pengantar Kesehatan Lingkungan. Jakarta : Penerbit Buku Kedokteran. 
Furnanda, R. (2012). Partisipasi Ibu Rumah Tangga Dalam Mewujudkan Program Medan Green And Clean (MdGC) Melalui Pengelolaan Bank Sampah Di Lingkungan II Kelurahan Tanjung Gusta Kecamatan Medan Helvetia Kota Medan. Repositori Universitas Sumatera Utara. Dari http://repository.usu.ac.id/hand le/123456789/33688

Ismawatu A. (2013). Gambaran Partisipasi Masyarakat Dalam Pengelolaan Sampah Pada Bank Sampah UKM Mandiri Di Rw 002 Kelurahan Tamamaung, Kecamatan Panakkukang, Kota Makassar. Repository UIN Alauddin Makassar. Dari : http://repositori.uinalauddin.ac.id/3165/

Isthofani E S Dkk,. (2016). Persepsi dan pola Perilaku Masyarakat Bantara Sungai Damar Dalam Membuang Sampah Di Sungai. UNNES Universitas Negri Semarang Indonesia Journal of Innovative science Education 5 (2):p-ISSN 2252-6412,e-ISSN 2502-4523.

Malia I. (2018). Volume Sampah 2018 Diprediksi Mencapai 66, 5 Juta Ton. Dipetik November, 12, 2018.

Dari :
https://www.idntimes.com/new s/indonesia/indianamalia /volume-sampah-2018diprediksi-mencapai-665-jutaton-1
Manto Dkk. (2013). Analisis Pengelolaan Sampah Padat Di Kecamatan Banuhampu Kabupaten Agama. Jurnal Kesehatan Masyarakat Andalas, 10(2), 157-165.

Mubarak Ikbal \& Chayatin N. (2009). Ilmu Kesehatan Masyarakat. Jakarta: Salemba Medika.

Mukono. (2007). Dasar-Dasar Kesehatan Lingkungan. Surabaya: Erlangga University Pres.

Notoatmodjo, S,. (2007). Kesehatan Masyarakat Ilmu Dan Seni. Jakarta: Rineka Cipta

Sulistiyorini R N. Dkk. (2015). Partisipasi Masyarakat dalam Pengelolaan Sampah di Lingkungan Margaluyu Kelurahan Cicurug. SHARE: Social Work Journal, 5(1).

Syarifa F, (2014). Model Konseptual untuk Mengukur Adaptabilitas Bank Sampah di Indonesia. J@ ti Undip: Jurnal Teknik Industri, 9(1), 19-28.

Uniplaita, A. (2014). Buku Putih Sanitasi Kabupaten Kepulauan Aru. Badan Pusat Statistik. Dari:http://ppsp.nawasis.info/d okumen/perencanaan/sanitasi/p okja/bp/kab.kepulauan aru/ BPS\%20REVIEW\%20FINAL. pdf

Winda, Juliani, Any, et al. (2012) Pengaruh Penambahan Kosubstrat Pada Biodegradasi 
Crude Oil. Jurnal Sains dan Teknologi Lingkungan, 8(2), 112-120.

Yusriani, Y., \& Alwi, M. K. (2018).
Dan

Pemberdayaan

Masyarakat. Book \& Articles Of Forikes, 9, 1-59.

Buku Ajar Promosi Kesehatan 